\title{
Delivery of stromal cell-derived factor $1 a$ for in situ tissue regeneration
}

\author{
Wen Zhao ${ }^{{ }^{*}}$, Kaixiang Jin ${ }^{1}$, Jiaojiao $\mathrm{Li}^{1}$, Xuefeng $\mathrm{Qiu}^{2}$ and Song $\mathrm{Li}^{2^{*}}$
}

\begin{abstract}
In situ tissue regeneration approach aims to exploit the body's own biological resources and reparative capability and recruit host cells by utilizing cell-instructive biomaterials. In order to immobilize and release bioactive factors in biomaterials, it is important to engineer the load effectiveness, release kinetics and cell recruiting capabilities of bioactive molecules by using suitable bonding strategies. Stromal cell-derived factor 1a (SDF-1a) is one of the most potent chemokines for stem cell recruitment, and SDF-1a-loaded scaffolds have been used for the regeneration of many types of tissues. This review summarizes the strategies to incorporate SDF-1a into scaffolds, including direct loading or adsorption, polyion complexes, specific heparin-mediated interaction and particulate system, which may be applied to the immobilization of other chemokines or growth factors. In addition, we discuss the application of these strategies in the regeneration of tissues such as blood vessel, myocardium, cartilage and bone.
\end{abstract}

Keywords: In-situ tissue engineering, Stromal cell-derived factor, Cell-instructive biomaterials, Bonding interaction, Chemokine

\section{Background}

Tissue engineering combines the knowledge and technologies in engineering, biology and medicine to promote the regeneration of tissues and the restoration of tissue and organ function. In the past two decades, the approaches of tissue engineering have evolved to facilitate the translation of research findings and technologies into clinical applications [1-3]. A classical approach of tissue engineering is to fabricate bioengineered tissues or organs by culturing allogeneic or autologous cells on the scaffold in vitro, followed by the implantation of the cellular constructs. However, this strategy presents several notable disadvantages: cell culture is costly and time-consuming; there may be a phenotypic change of the cells during cell expansion, cellular construct has limited shelf life and is vulnerable to contamination; and only a fraction of seed cells actually contribute to tissue formation. Recent progress in tissue engineering and regenerative medicine has resulted in the adoption of the concept of the utilization of cell-instructive biomaterials with bioactive molecules for in situ tissue engineering $[4,5]$.

\footnotetext{
* Correspondence: wenzhao@nwpu.edu.cn; songli@ucla.edu

${ }^{1}$ Key Laboratory for Space Biosciences and Biotechnology, School of Life Sciences, Northwestern Polytechnical University, Xi'an, Shaanxi 710072, China ${ }^{2}$ Department of Bioengineering and Department of Medicine, University of California, Los Angeles, CA 90095, USA
}

Rather than implanting cells or tissue grown in vitro, in situ tissue engineering involves the implantation of bioactive scaffold material decorated with, or eluting, bioactive factors into the tissue defect in order to engage the natural regeneration capacity of the host by recruiting stem cells or progenitor cells. In some types of tissues, the number of adult stem cells surrounding an implanted scaffold may be too low to have a significant impact on the acceleration of tissue regeneration [4]. Recent studies have proven that stem cells from the blood circulation can play a significant role in vascularization, hematopoiesis and mesenchymal tissue regeneration [6, 7]. Therefore, it is also valuable to mobilize progenitors from the peripheral blood system.

Stromal cell-derived factor- $1 \alpha$ (SDF- $1 \alpha)$ is a member of the CXC chemokine family of pro-inflammatory mediators and a potent chemoattractant for a variety of cells, especially CXC chemokine receptor type 4 (CXCR4) positive progenitors $[8,9]$. Upon injury, cells from the injured tissue express and release a high level of SDF- $1 \alpha$, which causes a concentration gradient of SDF-1 $\alpha$ from injured tissue to the surrounding microenvironment. CD34+ progenitor cells from the peripheral blood circulation can be recruited via chemotactic attraction toward this gradient $[10,11]$. Some 
investigators have also reported on the role of SDF$1 \alpha$ in the mobilization and recruitment of bone marrow-derived hematopoietic stem cells (HSCs) and mesenchymal stem cells (MSCs), which contribute to the regeneration of blood vessels, bone, cartilage, skeletal muscle [12-15]. Some researchers have noted that the existence of SDF- $1 \alpha$ around an in-situ tissue regeneration scaffold induces cell migration to the scaffold $[15,16]$. Therefore, incorporation of SDF- $1 \alpha$ into a suitable tissue engineering scaffold is an effective method of recruiting host circulating stem cells to the target tissue.

Both loading capacity and the release property of SDF$1 \alpha$ are critical for tissue regeneration. All of the controlled release characteristics are dependent on how SDF- $1 \alpha$ is incorporated into the scaffolds. Hence, this review summarizes various bonding strategies of SDF- $1 \alpha$ in biomaterials. Additionally, the typical applications of SDF- $1 \alpha$-loaded scaffolds in the regeneration of blood vessels, myocardium, cartilage and bone are discussed.

\section{Bonding strategies}

In order to achieve in situ tissue regeneration, the release kinetics, loading efficiency and quantity of SDF- $1 \alpha-$ loaded scaffolds can be engineered through different bonding strategies. Generally speaking, bonding between scaffolds and SDF- $1 \alpha$ can be classified as physical and chemical immobilization. Importantly, the premature degradation of SDF- $1 \alpha$ should also be prevented $[17,18]$. Table 1 provides a summary of SDF$1 \alpha$ bonding strategies that have been developed.

Compared with chemical bonding, physical adsorption is weaker, and has a burst release and short release duration. Ji et al. suggests that this initial burst release of SDF- $1 \alpha$ is responsible for a more effective recruitment of stem/progenitor cells and so conducive of superior clinical outcome [19]. However, Chen et al. holds the opposite point of view [20]. They emphasize that the rapid elution of SDF-1 $\alpha$ may lead to some adverse effects. For example, SDF- $1 \alpha$ can be cleaved by various enzymes including dipeptidylpeptidase-4 (DPP-4), metalloproteinases (MMPs), neutrophil elastase and cathepsin G, leading to the generation of neurotoxic products which known to be involved in some forms of dementia [21-25].

Chemical immobilization of bioactive factors onto the surface of scaffolds is generally superior to physical immobilization in tissue engineering applications to prevent them being washed out when the scaffold is in contact with fluid over an extended period. Furthermore, the loading efficiency of chemically immobilized bioactive factors is generally higher, which avoids wasting bioactive factors during fabrication. However, denaturation and the loss of bioactivity might happen during chemical immobilization due to exposure of the loaded bioactive factors to organic-aqueous interfaces [26, 27]. In addition, the loading procedure is more complicated than for physical adsorption.

As the synergistic effects between SDF- $1 \alpha$ and multiple chemokines have been observed [28], selecting appropriate bonding strategy for each of the bioactive factors is also challenging.

Here we review typical bonding strategies SDF- $1 \alpha$ immobilization. We also introduce some technologies that can be used for the loading of SDF- $1 \alpha$.

\section{Direct loading or adsorption}

Direct loading or adsorption of bioactive factors onto biomaterials is widely used. In this case, chemokines such as SDF- $1 \alpha$ are incorporated during the fabrication process of the scaffolds, especially hydrogels, because the reaction process is relatively mild allowing chemokine bioactivity to be retained [29-32]. Alternatively, physical adsorption can be done by immersing porous scaffolds in a solution of SDF- $1 \alpha$ or injecting SDF- $1 \alpha$ into the scaffold [33-35]. The incorporated SDF-1 $\alpha$ can be released upon the desorption from the scaffold or the degradation of the scaffold. The release kinetics of this type of scaffold shows a burst release during the first few hours and subsequently stable release over the following few days [19]. However, the loading efficiency of this kind of scaffold is usually poor.

Some researchers have attempted to improve the adsorption efficiency of protein-loaded scaffolds by some specific methods that could be employed to load SDF- $1 \alpha$ into a scaffold. For instance, Koh and his colleagues [36] used inductively-coupled radio-frequency glow discharge plasma, normally used to clean biomaterials, to improve the poor loading efficiency of the physical adsorption process. The plasma could trigger a reaction with polymer scaffolds and break the chemical bonds on the surface. Thus, the surface reactivity of scaffolds was increased, making it easy for bioactive factors to be absorbed upon the immersion of the scaffolds in a solution of chemokine.

Direct loading or adsorption processes are relatively simple and time-saving. However, the burst release kinetics, short release duration and poor loading efficiency limit its application.

\section{Immobilization through the formation of polyion complexes}

Polyion complexes are formed by electrostatic interactions between charged polyelectrolytes and their oppositely charged partners [37, 38]. The interactions are relative stable because it would be statistically impossible for all the ionic interactions on the molecules to dissociate concurrently [39]. This approach does not require additional modification of delivery matrices or linker 
Table 1 Bonding strategies of SDF-1a-loaded scaffolds

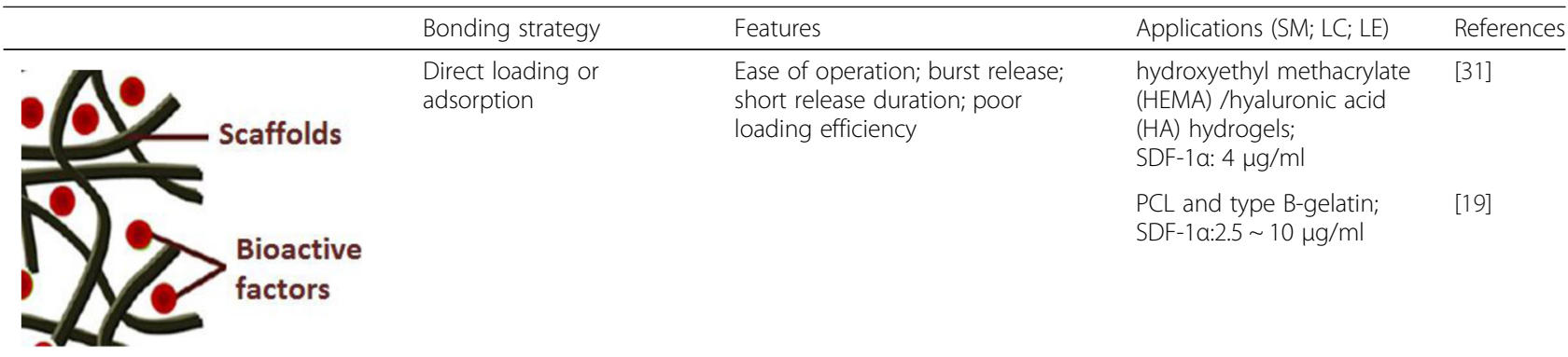

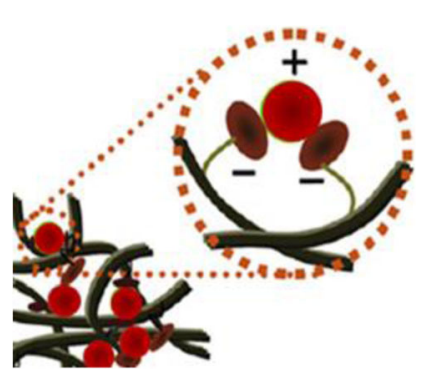

Immobilization through the formation of ionic complexes
Extensive applicability; efficient dsorption; free of linker molecules; less dependent on surface properties; adjustable release rate; requires cytotoxic surfactants
PGS (PEDA/heparin

coacervate);

SDF-1 a:8 $\mu \mathrm{g} / \mathrm{ml}$

Efficiency:94.3\%

PPCN;

SDF-1a:0.5 $\mu \mathrm{g} / \mathrm{ml}$

Efficiency:102.8\%
[51]

19\%PLLA 5\%PCL (w/v): SDF-1a:0.5 $\mu \mathrm{g} / \mathrm{ml}$

StarPEG-heparin hydrogel; SDF-1a:2.5 $15 \mu \mathrm{g} / \mathrm{ml}$; Efficiency: $99.6 \%$

Co-Cr plates; SDF-1a:0.25 $2 \mu \mathrm{g} / \mathrm{ml}$ SDF-1a:0.1 $\mathrm{\mu g} / \mathrm{ml}$ Efficiency: $97.5 \%$

PLGA nanoparticles

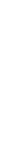

Dex-GMA/gelatin microcapsules (PNIPAAm thermo gates):

[20] duration; multiple proteins load; complex operation

\section{Micro-capsule}

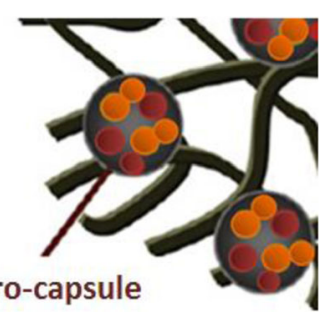

Particulate systems

Abbreviations: SM scaffold materials, $L C$ loading concentration, $L E$ loading efficiency

molecules for covalent crosslinking before the incorporation of bioactive factors. Generally speaking, polyion complexes can be used for the controlled release of multiple charged therapeutic agents such as polysaccharides, proteins, polynucleotides and oligo through their coupling to fibers [40, 41] or microcapsules [42-46]. A typical positively-charged polymer material is chitosan, while commonly used negatively-charged polymer materials include sodium carboxymethyl cellulose, sodium alginate, hyaluronic acid and polyacrylates.

Liao et al. [40] introduced the interfacial polyelectrolyte complexation technology to produce drug-loaded chitosan-alginate fibers. Bioactive agents are dispersed into either the alginate or chitosan solution prior to fiber formation. By varying the ratio of the components in the anionic or cationic polyelectrolyte solution, the release behavior of the protein or growth factor can be significantly altered. In some studies, scaffold materials were chosen with an isoelectric point (IEP) that achieved a better coating rate and loading capacity of SDF- $1 \alpha[35,47-49]$. When the $\mathrm{pH}$ of the medium is greater than the IEP of the scaffold component, the material easily absorbs cations, and conversely, when the $\mathrm{pH}$ of the medium is less than the IEP, the 
material tends to absorb anions [47]. This theoretically allows electrostatic interactions to adjust between a charged bioactive factors and an oppositely charged molecule by changing the $\mathrm{pH}$ of the medium. In particular, SDF- $1 \alpha$ has a net charge of +8 at $\mathrm{pH}$ 7.4 (IEP of SDF-1 $\alpha$ : 9.9) [50], so it is more efficient to load into a negatively charged scaffold. In short, the release kinetics and loading efficiency of coupled bioactive factors can easily be modulated by modifying the ionic strength, charge density, $\mathrm{pH}$ and the interacting scaffold.

Lee et al. [51] used a strong polycation to neutralize excess negative charges on heparin molecules to drive spontaneous coacervation. Since coacervation is a phase separation process, the coating method is less dependent on the surface properties of the scaffold $[52,53]$. Thus, SDF- $1 \alpha$ coacervate can easily be incorporated and uniformly dispersed on the surface of poly(glycerol sebacate) (PGS) scaffolds in aqueous solution without any exogenous chemicals. Furthermore, SDF- $1 \alpha$-loaded coacervate did not block existing pores and created a natural SDF- $1 \alpha$ gradient from surface to the deeper layer of the porous scaffold, allowing stem/progenitor cell homing.

Immobilization of SDF- $1 \alpha$ through polyion complexes is free of linker molecules, is less dependent on the surface properties of scaffold, and allows easy adjustment of release rate. However, the process requires polarity matched bioactive factors and polymer materials which may limit its application.

\section{Immobilization through specific heparin-mediated interaction}

Heparin is a highly sulfated polysaccharide which is commonly used as an anticoagulant. Through specific heparin-mediated interactions with chemokines [54], chemokines can be protected from premature degradation, playing a crucial role in maintenance of physiological chemokine function. In particular, SDF- $1 \alpha$ binds to heparin sulfate through a typical consensus sequence for heparin recognition. Lys-1, Lys-24, Lys-27 and Arg41 on the surface of SDF- $1 \alpha$ are essential for its interaction with heparin [54-56].

Commonly, heparin is crosslinked with the components of the hydrogel, and SDF- $1 \alpha$ in aqueous solutions interacts with the modified hydrogel through a specific heparin-mediated interaction [16, 57-60]. Alternatively, heparin can also be covalently linked to polymer scaffolds through linker molecules. SDF- $1 \alpha$ is then immobilized to the conjugated heparin through its heparinbinding domain [61]. For example, $\mathrm{Yu}$ et al. [47] employed $\mathrm{NH}_{2}$-PEG-NH $\mathrm{N}_{2}$ as a linker molecule attached to the carboxylic acid groups of microfibers, and then covalently attached heparin to the free amines of the
$\mathrm{NH}_{2}$-PEG- $\mathrm{NH}_{2}$ molecules using carbodiimide chemistry [62]. Finally, SDF-1 $\alpha$ was bound to heparin via the specific interaction between them. This approach ensures that the scaffold can recruit target cells in addition to the anti-coagulation property [54]. This study demonstrated that SDF-1 $\alpha$ immobilization on the scaffolds was stable with a sustained release of SDF- $1 \alpha$ over one week in vitro. In addtion, SDF- $1 \alpha$ loading efficiency is three times higher than the direct adsorbing process [47].

In order to mimic native extracellular matrices that provide mechanical support and chemical signals, Tsurkan et al. [63] introduced a class of biodegradable hydrogel that tunes its mechanical properties by the modulation of the degree of crosslinking and degradation by a specific enzyme. Specifically, all four arms of a hydroxyl-terminated star-polyethylene glycol (sPEG) were modified with acrylate groups (forming sPEG-Acl). These acrylate groups were then coupled with an MMPcleavable peptide sequence. In the last procedure, the $\mathrm{N}$ terminal amino groups of the sPEG-peptide were linked to carboxylic groups of heparin molecules to create a three dimensional network. Bioactive factors, such as SDF-1 $\alpha$, could be loaded to the network through the specific heparin-mediated interaction. Furthermore, the degradation rate of the hydrogel could be further modulated by using peptides with different enzymatic sensitivity, hence expanding the application area of the SDF- $1 \alpha$ heparin containing scaffold.

Compared with direct loading or adsorption, loading efficiency of SDF- $1 \alpha$ is improved dramatically due to electrostatic interactions between the positively charged region of SDF- $1 \alpha$ and negatively charged sulfate groups of heparin $[54,56]$. Besides, the sustained release property of the loaded protein is also improved due to the improved bonding strength. Furthermore, the influence of the loading capacity on release profile should not be ignored. Generally speaking, the more protein contained within the scaffold the stronger the burst release will be. Some researchers have noted that the concentration of SDF- $1 \alpha$ around heparin-mediated scaffolds influences cell migration $[15,16,64]$. Thus, it is necessary to ensure that the dose of loaded SDF- $1 \alpha$ matches the regeneration process of the injured tissue.

In short, immobilization of SDF- $1 \alpha$ through specific heparin-mediated interactions is widely used in scaffolds for in situ tissue engineering due to its strong interaction, efficient adsorption and reduced degradation. Nevertheless, the bonding process is relatively complicated.

\section{Particulate systems}

Micro/nano particles carriers are widely employed in fabricating controlled drug delivery systems. The direct loading or adsorption of a chemokine into a particulate 
system is relatively convenient to achieve. However, it is associated with various issues such as high burst release, protein aggregation and denaturation. In order to prevent the burst release, some investigators employed microemulsion spheres to load the chemokine. In particular, Cross and colleagues [65] incorporated SDF-1 $\alpha$ with poly(lactide-co-glycolide) (PLGA) microspheres using a double emulsion solvent extraction/evaporation technique to achieve sustained release of SDF- $1 \alpha$ over 50 days. Additionally, $\mathrm{Wu}$ et al. [66] applied carboxyl-polyethylene glycol-4000-carboxyl (COOH-PEG4000-COOH) to the surface of their microemulsion spheres. This allowed SDF- $1 \alpha$ to bind the microparticle through amide bonds, enhancing loading efficiency. The loaded chemokine could be released from the micro emulsion bubble by directed ultrasonic waves. However, utilizing emulsification techniques to fabricate protein-encapsulated particles may result in protein denaturation and the loss of bioactivity, due to exposure of protein to organic-aqueous interfaces [26]. Zamani et al. [27] introduced coaxial electrospraying to prevent protein denaturation during the fabrication process by reducing the contact time of the bioactive factors with other reactants.

In addition, micro- or nanoparticle-incorporated hydrogels have also been widely investigated to control the delivery of chemokines for tissue engineering applications, such as bone or cartilage regeneration [37, 67, $68]$. Both temporally and spatially controlled release of these bioactive molecules in specific sites have been proved, thus being valuable in modulating the behavior of encapsulated cells. Nevertheless, the loss of bioactivity in encapsulated molecules due to high temperatures, organic solvents, and/or shear stress during the fabrication of the micro- or nanoparticles is likely unavoidable.

Recently, In order to create smart scaffolds that control chemokine release with time-specific, sitespecific and rate programmed characteristics, some environmental stimuli-responsive microcapsules have been researched [69-71]. Chen et al. [20] developed a delivery system to control the release of SDF- $1 \alpha$ by making microcapsules containing thermo-sensitive polymeric gates on their outer pore surfaces. The pore surfaces of the microcapsules was grafted by poly( $\mathrm{N}$-isopropylacrylamide) (PNIPAAm) using plasma-graft pore-filling polymerization. The grafted PNIPAAm were in swollen state at ambient temperature, causing the pores in the outer surfaces to be blocked and thus the release rate of SDF- $1 \alpha$ was low. While the temperature was above $22{ }^{\circ} \mathrm{C}$, grafted PNIPAAm were in shrunken state, causing the pores in the outer surfaces to be opened, with a corresponding increase in the release rate of loaded SDF-1 $\alpha$. In addition to PNIPAAm, a copolymer called poly(polyethylene glycol citrate-co$\mathrm{N}$-isopropylacrylamide) (PPCN) is also characterized by its thermoresponsive behavior, antioxidant properties and morphology, and has received attention in protein delivery [72]. Kim et al. [73] has employed a $\mathrm{pH}$ sensitive copolymer named poly (urethane amino sulfamethazine) (PUASM) to load SDF-1 $\alpha$. The polymer forms micelles and encapsulates proteins effectively via ionic interaction at physiological $\mathrm{pH}$. At environmental $\mathrm{pH}$ lower than 5.5, the micelle disassembles due to the ionization of tertiary amines, releasing the encapsulated protein.

Self-assembled monolayer deposition is often used to fabricate heparin-coated nanoparticles that could be utilized to load SDF-1 $\alpha$ through specific heparin-mediated interactions. Specifically, a polyelectrolyte layer can be deposited onto an oppositely charged substrate through electrostatic adsorption. $\mathrm{Na}$ et al. [74] developed a heparin/ poly(L-lysine) self-assembled nanoparticle-immobilized PLGA microsphere system, and showed that the specific binding activity of heparin allowed the loading of different bioactive factors. Wang [18] discovered that load capability and release kinetics of bioactive factors immobilized on self-assembled particles can be modified simply by changing the ratio of heparin to polymer.

At present, some investigators have proposed the use of particulate systems to load multiple bioactive factors by physical absorption to facilitate tissue repair in the body [75]. Richardson et al. [76] investigated a tissue-specific delivery system to deliver two or more bioactive factors. The first approach involved simply mixing lyophilized vascular endothelial growth factor (VEGF) with polymer particles before processing the polymer into a porous scaffold. The second approach involved pre-loading the bioactive factor in PLGA microspheres, and then fabricating scaffolds with these particles. These approaches provided distinct release kinetics for each bioactive factor. A composite scaffold comprising drug-loaded fiber and bioactive factor-loaded microspheres was prepared by simultaneous electrospinning and electrospraying in our recent work. The in vitro release test showed that the release properties of the drug and the bioactive factor were distinct (unpublished observation). In fact, the multiple bioactive factors-loaded particle system(including SDF- $1 \alpha$ ) has been investigated by many researchers (Table 2). However, the optimization of the synergistic factors to promote the tissue regeneration process remains to be done.

In summary, particulate systems are able to control the release kinetics of bioactive factors. Furthermore, the system allows multiple factors to be loaded into scaffolds efficiently.

\section{Applications}

\section{Vascular scaffolds}

Replacement of diseased arteries is a common treatment. More than 500,000 vascular grafts are used for coronary 
Table 2 Synergistic effect between SDF-1a and other bioactive factors

\begin{tabular}{|c|c|c|c|c|}
\hline Bonding strategy & Factors & Implant position & Scaffold & References \\
\hline \multirow{2}{*}{$\begin{array}{l}\text { Direct loading or adsorption } \\
\text { (Adsorb solution through inject) }\end{array}$} & \multirow[t]{4}{*}{ SDF-1a and BMP-2 } & \multirow[t]{2}{*}{ Mouse, calvarial defects } & Commercial collagen $^{a}$ & [94] \\
\hline & & & Gelatin hydrogels & [95] \\
\hline \multirow{6}{*}{$\begin{array}{l}\text { Direct loading or adsorption } \\
\text { (Direct loading during } \\
\text { manufacture process) }\end{array}$} & & $\begin{array}{l}\text { Mouse, ulna critical-sized } \\
\text { defect }\end{array}$ & Degradable hydrogels & [96] \\
\hline & & $\begin{array}{l}\text { Mouse, calvarial defects/ } \\
\text { subcutaneous sites }\end{array}$ & Commercial collagen ${ }^{b}$ & [97] \\
\hline & SDF-1a and VEGF & $\begin{array}{l}\text { Mouse, calvarial defects/ } \\
\text { subcutaneous sites }\end{array}$ & Commercial collagen ${ }^{b}$ & [97] \\
\hline & $\begin{array}{l}\text { SDF-1a and platelet-derived } \\
\text { growth factor (PDGF) }\end{array}$ & $\begin{array}{l}\text { Mouse, calvarial defects/ } \\
\text { subcutaneous sites }\end{array}$ & Commercial collagen ${ }^{\text {b }}$ & [97] \\
\hline & SDF-1a and simvastatin & Mouse, calvarial defects & PLGA & [117] \\
\hline & $\begin{array}{l}\text { SDF-1a and insulin-like growth } \\
\text { factor-1 (IGF-1) }\end{array}$ & $\begin{array}{l}\text { Rat, lateral gastrocnemius } \\
\text { muscle of the TK-injured } \\
\text { limb }\end{array}$ & PEGylated fibrin gel matrix & [98] \\
\hline
\end{tabular}

Resorbable atelocollagen sponges (Teruplug; Terudermis Olympus Terumo Biomaterials Co.)

${ }^{\mathrm{b}}$ Collagen scaffold (Geistlich Pharma AG)

artery or peripheral arterial replacement each year [47]. However, autologous arterial and venous graft material has already been deployed, or is simply unusable may not be available in many cases [77]. Frequent occlusion and thrombosis in smaller grafts $(<6 \mathrm{~mm})$ limits the application of synthetic vascular grafts. Furthermore, the long-term patency rate of the synthetic vascular grafts is rather low due to the lack of endothelialization [47]. Tissue engineered vascular grafts are typically cell-based constructs. However, harvesting vascular cells, in vitro cell culture and making the grafts may take months. Therefore, in situ regeneration approach that recruits host cells is attractive.

SDF- $1 \alpha$ is a promising chemoattractant of host EPCs and MSCs because it induces host progenitor cell mobilization and recruitment by binding to receptors CXCR4 and CXCR7. However, direct injection of SDF$1 \alpha$ is problematic. The short circulation half-life and extraneous interactions with multiple binding sites all reduce its local concentration.

Thus, it is vital to control the release of SDF- $1 \alpha$ from vascular grafts by using an appropriate bonding method. Heparin could prevent thrombus formation [16, 47, 55], and also serve as an adapter for SDF- $1 \alpha$ binding. For instance, $\mathrm{Yu}$ et al. [47] used $\mathrm{NH}_{2}-\mathrm{PEG}-\mathrm{NH}_{2}$ to link heparin with polymer scaffolds, and then immobilized SDF- $1 \alpha$. Compared with physically-adsorbed SDF-1 $\alpha$, heparinbond SDF- $1 \alpha$ was more stable and demonstrated sustained release of SDF-1 $\alpha$. Furthermore, the in vivo test revealed that the inner surfaces of the graft were covered by endothelial cells that had differentiated from EPCs. Six months post implantation, many microvessels were found in the outer part of the scaffolds indicating that heparin + SDF- $1 \alpha$ treated grafts had been well vascularized.
Lee et al. [51] used heparin and a polycation to form a coacervate that was incorporated into PGS scaffolds. This strategy also provided long-term sustained release of SDF- $1 \alpha$ in open porous structured vascular scaffolds, which favored vascular regeneration. Finally, SDF-1 $\alpha$-containing nanoparticles have also been used for vascular grafts because of their sustained release characteristics [76, 78].

SDF-1 $\alpha$-loaded vascular grafts have many advantages, such as cell-free and available off-the-shelf. However, modulation of the release property of SDF-1 $\alpha$ on grafts to match the rate of regeneration in vivo is still challenging.

\section{Articular cartilage scaffolds}

Articular cartilage defects can be classified as partialthickness, full-thickness and osteochondral defects. Partial-thickness defects are the defects in the surface of articular without penetratingthe tidemark, while osteochondral defects are those that penetrate through the tidemark and subchondral bone until the bone marrow. Full-thickness defects are between the tidemark and bone marrow. Researchers found that osteochondral and full-thickness defects can heal spontaneously $[79,80]$ while partial-thickness defects cannot [81-83], which is attributed to the migration of stromal cells from bone marrow. Thus, It can be inferred that recruiting stem cells especially bone marrow stem cells (BMSCs) after articular cartilage damages is important to rebuild the defects.

Wei et al. [84] believe that bone marrow secreted SDF- $1 \alpha$ around the subchondral bone is the key point to affect the self-repair ability compared with fullthickness, osteochondral defects and partial-thickness defects. Zhang et al. [85] presented an effective strategy 
to create an in situ matrix environment by implanting an SDF-1 $\alpha$-containing type one collagen (Col1) scaffold. Col1 or Col $1+$ SDF-1 $\alpha$ scaffold were employed to coverpartial-thickness defects created on the patellar groove of rabbits. Meanwhile, untreated defects were regarded as control group. The Col1+ SDF-1 $\alpha$ group had a significantly higher histological macroscopic score for moderate neo-tissue coverage, surface regularity, and a smoother connection with the host cartilage. This revealed that the matrix environment created by SDF- $1 \alpha$ loaded Col1 scaffold did improve the spontaneous regeneration capacity of partialthickness defects.

Compared with the self-healing process of articular cartilage, the regenerated tissue treated by SDF- $1 \alpha$ scaffold has mechanical properties that are more similar to the original. Sukegawa et al. [86] used SDF-1 $\alpha$-loaded alginate gel to repair osteochondral defects. A fullthickness osteochondral defect was created in the patella groove of the distal femur in rabbits. The compressive modulus of regenerated tissues and the histological scores demonstrated prominent improvement compared with the blank control group.

One of the current limitations of bone and cartilage tissue engineering is the lack of sufficient blood supply in the initial phase following implantation [87]. Meanwhile, vascularization of the implant proceeds slowly and only a few blood vessels reach the center of the scaffold after several weeks [88]. Inadequate vascularization following implantation results in nutrient deficiency, which then leads to cell death in the tissue-engineered scaffolds $[89,90]$. In order to efficiently enhance migration of vascular cells into the scaffold, Chen et al. [91] fabricated a collagen scaffold with radially oriented channels and investigated its cell recruit property in combination with SDF-1 $\alpha$. They found that cells infiltrated further into the center of the scaffold. Besides, Brouwer and his colleagues also designed a scaffold with radial pore structure to repair the diaphragm defects, and reached the same conclusion [92, 93]. The in vivo experiments on rabbits confirmed that BMSCs could also be recruited into the radially-oriented scaffold with the assistance of SDF- $1 \alpha$.

Although SDF-1 $\alpha$ loaded articular cartilage scaffolds have been widely researched, the regenerated tissue is still different from natural articular cartilage both in structural constitution and mechanical properties. Further study is necessary to optimize the structure and component of the scaffolds, as well as loading capacity and release property of SDF-1 $\alpha$.

\section{Osseous scaffolds}

Currently, SDF- $1 \alpha$-loaded scaffolds have been widely used to repair bone defects (Table 2), and there is an increasing amount of work addressing the synergy of SDF-1 $\alpha$ with other bioactive factors for bone repair [15, 94-98].

Ratanavaraporn et al. [28] evaluated the activity of gelatin hydrogels combined with SDF-1 $\alpha$ and bone morphogenetic protein 2(BMP-2) on bone regeneration at an ulna critical-sized defect of rats. The result demonstrated that a SDF- $1 \alpha$ and BMP-2-loaded scaffold was more effective to induce bone regeneration than a scaffold loaded with either factor alone. Other researchers also found the same effect and provided some possible explantion. On the one hand, synergetic effect of SDF$1 \alpha$ and BMP-2 may influence the SDF- $1 \alpha /$ CXCR 4 or other signal pathways to enhance cell recruitment around scaffold. On the other hand, the enhanced recruitment of HSCs improves the vascularization, which helps to supply nutrient [99-101]. Furthermore, the SDF- $1 \alpha$ and BMP-2 signaling may activate osteogenic differentiation, which improve the bone regeneration $[102,103]$.

It is well known that several members of the BMP family, including BMP-2, $-4,-6,-7$, and -9 , can induce MSCs to undergo osteogenic differentiation and promote bone formation [104-107]. However, using BMPs has some disadvantages, including ease of degradation and high cost [108-110]. Simvastatin (SIM) is a competitive inhibitor of 3-hydroxy-3-methyl coenzyme A (HMGCoA) reductase, which improves the osteogenesis of adipose-derived stromal cells (ASCs) [111]. Meanwhile there have been many studies demonstrating the promotion of bone regeneration by the local application of SIM with different delivery systems in various animal models [112-115]. Furthermore, SIM has recently been shown to mobilize MSCs migrating to bone defects or areas of spinal cord injury [116]. Thus, Liu et al. [117] fabricated a PLGA-based cell-free bone tissue engineering scaffold loaded with SIM and SDF-1 $\alpha$, and applied it in critical-sized calvarial defects in mice. Their findings suggest that the combination of SDF- $1 \alpha$ and SIM increases MSCs migration and homing, promotes angiogenesis and enhance the expression of BMP-2 in newly-formed bone tissue.

Richardson et al. [76] investigated a polymeric system that allowed for the tissue-specific delivery of two or more bioactive factors with controlled dose and release rate. Briefly, a porous PLGA scaffold loaded with multiple growth factors was fabricated by a high-pressure carbon dioxide fabrication process. Two types of strategy were used to load bioactive factors, processing the polymer into a porous scaffold. One bioactive factor was simply mixed with polymer particles which lead to rapid release. Another bioactive factor was pre-encapsulated in PLGA microspheres which lead to a comparatively 
slower release rate. The scaffold was fabricated with these particles.

The therapeutic effect of multiple bioactive factors contained within the scaffold system was more dramatic than the single factor system. Nevertheless, there are still many problems which limit its development. For instance, the preparation process of the scaffold with its multiple bioactive factors is complicated, and its molecular mechanism and the safety of the system remain to be investigated. In order to mimic the process of natural bone healing, the ideal smart multiple bioactive factors loaded scaffold system should control the release sequence as well as the release rate of each factor.

\section{Myocardium scaffold and other applications}

The deterioration of cardiac function following myocardial infarction (MI) is a major cause for high mortality due to heart disease [118]. It is important to ensure myocardium regenerates after MI. As for cell therapy, poor cell engraftment in the myocardium limits the efficiency of using stem/progenitor cells to treat MI [31]. Investigators have demonstrated that myocardial SDF$1 \alpha$ expression is temporarily increased following MI $[119,120]$; however, long-term SDF- $1 \alpha$ release is necessary for cardiac regeneration.

As for SDF- $1 \alpha$-loaded MI scaffolds, achieving sustained release and preventing premature enzymatic degradation of the loaded chemokine are critical. Zhang et al. [32] introduced a PEGylated fibrin patch to deliver a sustained flux of SDF- $1 \alpha$ to an acute MI (AMI) site. Specifically, PEGylated fibrin patch was fabricated by mixing thrombin with SDF-1 $\alpha$ incorporated PEGylated fibrinogen. An in vitro study demonstrated that SDF- $1 \alpha$ was successfully released from the patch over 10 days. The in vivo release study in mouse MI model indicated that the controlled release of SDF- $1 \alpha$ from a PEGylated fibrin patch significantly recruited more c-kit + cells to the infarct area at the second week than did the direct injection group. This phenomenon was observed for up to 4 weeks following implantation. It revealed that SDF- $1 \alpha$ contained within a PEGylated fibrin patch could overcome premature degradation and it healed AMI through sustained chemokine release. Some researchers have adopted SDF-1 $\alpha$-linked hydrogel to achieve a long release duration and high loading efficiency for MI treatment $[16,31,121]$.

Despite recent research showing SDF-1 $\alpha$-loaded MI scaffolds could help to repair heart injury following MI, it remains a challenge to determine the best release property, especially the concentration of the chemokine around the scaffold for safe and efficient treatment.

This review only covers applications in several tissues. There are also studies on other tissue injures such as skin ulcers [49, 122], traumatic brain injury [123], and intervertebral disc degeneration [33] because of the ability of SDF-1 $\alpha$-loaded scaffolds to recruit cells.

\section{Conclusions}

SDF- $1 \alpha$-loaded scaffolds have been adopted to investigate the regeneration of blood vessels, myocardium, cartilage, bone and many other tissues. Most investigators adopt physical immobilization to load SDF- $1 \alpha$, especially direct loading or adsorption due to its ease of operation. Furthermore, immobilization of cues through the formation of ionic complexes is appropriate for the loading of SDF- $1 \alpha$ for its universality, relative strong interaction, lack of linker molecules, reduced dependence on surface properties, and the protection of immobilized factors from inactivation. However, the disadvantages of physical immobilization are also clear. Uncontrolled burst release and short release duration limit its application. In order to restrain the burst release and prolong the release duration of SDF-1 $\alpha$ from scaffolds, some researchers have introduced heparin-mediated immobilization. For example, an amidation reaction between heparin and scaffold has been utilized. SDF- $1 \alpha$ is then incorporated into the scaffold through the specific heparinmediated interaction. Furthermore, micro-carrier immobilization can also provide sustained release of SDF- $1 \alpha$ by loading bioactive factors into nano- or micro-polymer particles. The SDF- $1 \alpha$-loaded particle is mixed with raw materials to fabricate the scaffolds or simply coated on the surface of scaffolds. The most remarkable merit of the particulate system is that it provides microcarriers to load multiple bioactive factors that may promote effective cell migration, growth and differentiation. These bonding strategies may also be expanded to immobilize other chemokines or growth factors. For in vivo applications, it is critical to prevent the enzymatic degradation of SDF- $1 \alpha$ upon release from the scaffolds. Therefore, protease-resistant SDF- $1 \alpha$ may have potential applications for in situ tissue regeneration.

It has been found that the release kinetics, loading efficiency and cell homing capability of SDF- $1 \alpha$-loaded scaffolds depend on their bonding strategies. To mimic a physiological cellular microenvironment, one needs to consider the nature of the bonding strategy the scaffold should adopt for its application. It is likely that a SDF$1 \alpha$-loaded scaffold may be loaded with multiple bioactive factors through a combined use of different bonding strategies, in which synergistic effects of the bioactive factors can arise. Specifically, it may become a future trend to control the release sequence as well as the release rates of the multiple bioactive factors by choosing appropriate bonding strategies for each bioactive factor. 


\section{Abbreviations}

ASCs: Adipose-derived stromal cells; BMP-2: Bone morphogenetic protein 2; Col1: Type one collagen; CXCR4: CXC chemokine receptor type 4; DPP-4: Dipeptidylpeptidase-4; EPCs: Endothelial progenitor cells; HMGCoA: 3-hydroxy-3-methyl coenzyme A; HSCs: Hematopoietic stem cells; IEP: Isoelectric point; MI: Myocardial infarction; MMPs: Metalloproteinases; MSCs: Mesenchymal stem cells; PGS: Poly(glycerol sebacate); PLGA: Poly(lactide-co-glycolide); PNIPAAm: Poly(N-isopropylacrylamide); PPCN: Poly(polyethylene glycol citrate-co-N-isopropylacrylamide); PUASM: Poly(urethane amino sulfamethazine); SDF-1a: Stromal cell-derived factor 1a; SIM: Simvastatin; sPEG: Star-poly(ethylene glycol); VEGF: Vascular endothelial growth factor

\section{Acknowledgements}

This work was financially supported by the Fundamental Research Funds for the Central Universities of China (Program No. 3102015ZY085 \& No. 3102015BJ(II)MYZ15 to W. Zhao), Natural Science Basic Research Plan in Shaanxi Province of China (Program No. 2015JM5177 to W. Zhao) and National Institute of Health (HL117213 and HL121450 to S. Li).

\section{Funding}

Not applicable

\section{Availability of data and materials}

Not applicable

\section{Authors' contributions}

WZ, JK and SL conceived and planned the structure of the manuscript and wrote the manuscript. $J L$ and $X Q$ reviewed the applications and summarized the tables. All authors read and approved the final manuscript.

\section{Competing interests}

The authors declare that they have no competing interests

\section{Consent for publication}

Not applicable

\section{Ethics approval and consent to participate}

Not applicable

\section{Publisher's Note}

Springer Nature remains neutral with regard to jurisdictional claims in published maps and institutional affiliations.

Received: 9 November 2016 Accepted: 29 March 2017 Published online: 29 June 2017

\section{References}

1. Langer R. Editorial: tissue engineering: perspectives, challenges, and future directions. Tissue Eng. 2007;13:1-2.

2. Atala A, Bauer SB, Soker S, Yoo JJ, Retik AB. Tissue-engineered autologous bladders for patients needing cystoplasty. Lancet. 2006;367:1241-6.

3. Ouyang HW, Goh JCH, Thambyah A, Teoh SH, Lee EH. Knitted poly-lactideco-glycolide scaffold loaded with bone marrow stromal cells in repair and regeneration of rabbit Achilles tendon. Tissue Eng. 2003;9:431-9.

4. Ko IK, Lee SJ, Atala A, Yoo JJ. In situ tissue regeneration through host stem cell recruitment. Exp Mol Med. 2013;45:e57.

5. Li S, Sengupta D, Chien S. Vascular tissue engineering: from in vitro to in situ. Wiley Interdiscip Rev Syst Biol Med. 2014;6:61-76.

6. Wan C, He QL, Li G. Allogenic peripheral blood derived mesenchymal stem cells (MSCs) enhance bone regeneration in rabbit ulna critical-sized bone defect model. J Orthop Res. 2006;24:610-8.

7. Kuznetsov SA, Mankani MH, Gronthos S, Satomura K, Bianco P, Robey PG. Circulating skeletal stem cells. J Cell Biol. 2001;153:1133-9.

8. Peled A, Petit I, Kollet O, Magid M, Ponomaryov T, Byk T, Nagler A, Ben-Hur H, Many A, Shultz L, Lider O, Alon R, Zipori D, Lapidot T. Dependence of human stem cell engraftment and repopulation of NOD/SCID mice on CXCR4. Science. 1999;283:845-8.

9. Ceradini DJ, Kulkarni AR, Callaghan MJ, Tepper OM, Bastidas N, Kleinman ME, Capla JM, Galiano RD, Levine JP, Gurtner GC. Progenitor cell trafficking is regulated by hypoxic gradients through HIF-1 induction of SDF-1. Nat Med. 2004;10:858-64.

10. Lau TT, Wang D-A. Stromal cell-derived factor-1 (SDF-1): homing factor for engineered regenerative medicine. Expert Opin Biol Ther. 2011;11:189-97.

11. Aiuti A, Webb IJ, Bleul C, Springer T, GutierrezRamos JC. The chemokine SDF-1 is a chemoattractant for human CD34(+) hematopoietic progenitor cells and provides a new mechanism to explain the mobilization of CD34(+) progenitors to peripheral blood. J Exp Med. 1997;185:111-20.

12. Jin DK, Shido K, Kopp HG, Petit I, Shmelkov SV, Young LM, Hooper AT, Amano H, Avecilla ST, Heissig B, Hattori K, Zhang F, Hicklin DJ, Wu Y, Zhu ZP, Dunn A, Salari H, Werb Z, Hackett NR, Crystal RG, Lyden D, Rafii S. Cytokine-mediated deployment of SDF-1 induces revascularization through recruitment of CXCR4(+) hemangiocytes. Nat Med. 2006;12:557-67.

13. Zhou B, Han ZC, Poon MC, Pu W. Mesenchymal, stem/stromal cells (MSC) transfected with stromal derived factor 1 (SDF-1) for therapeutic neovascularization: enhancement of cell recruitment and entrapment. Med Hypotheses. 2007;68:1268-71.

14. Grefte S, Kuijpers-Jagtman AM, Torensma R, von den Hoff JW. Skeletal muscle fibrosis: the effect of stromal-derived factor-1 alpha-loaded collagen scaffolds. Regen Med. 2010;5:737-47.

15. Otsuru S, Tamai K, Yamazaki T, Yoshikawa H, Kaneda Y. Circulating bone marrow-derived osteoblast progenitor cells are recruited to the boneforming site by the CXCR4/stromal cell-derived factor-1 pathway. Stem Cells. 2008;26:223-34.

16. Prokoph S, Chavakis E, Levental KR, Zieris A, Freudenberg U, Dimmeler S, Werner C. Sustained delivery of SDF-1alpha from heparin-based hydrogels to attract circulating pro-angiogenic cells. Biomaterials. 2012;33:4792-800.

17. Seeger FH, Rasper T, Fischer A, Muhly-Reinholz M, Hergenreider E, Leistner DM, Sommer K, Manavski Y, Henschler R, Chavakis E, Assmus B, Zeiher AM, Dimmeler S. Heparin disrupts the CXCR4/SDF-1 axis and impairs the functional capacity of bone marrow-derived mononuclear cells used for cardiovascular repair. Circ Res. 2012;111:854-62.

18. Wang B, Tan L, Deng D, Lu T, Zhou C, Li Z, Tang Z, Wu Z, Tang H. Novel stable cytokine delivery system in physiological pH solution: chitosan oligosaccharide/heparin nanoparticles. Int J Nanomedicine. 2015;10:3417-27.

19. Ji W, Yang F, Ma J, Bouma MJ, Boerman OC, Chen Z, van den Beucken JJ, Jansen JA. Incorporation of stromal cell-derived factor-1alpha in PCL/gelatin electrospun membranes for quided bone regeneration. Biomaterials. 2013: 34:735-45.

20. Chen FM, Lu H, Wu LA, Gao LN, An Y, Zhang J. Surface-engineering of glycidyl methacrylated dextran/gelatin microcapsules with thermoresponsive poly(N-isopropylacrylamide) gates for controlled delivery of stromal cell-derived factor-1alpha. Biomaterials. 2013;34:6515-27.

21. Segers VFM, Tokunou T, Higgins LJ, MacGillivray C, Gannon J, Lee RT. Local delivery of protease-resistant stromal cell derived factor-1 for stem cell recruitment after myocardial infarction. Circulation. 2007;116:1683-92.

22. Proost $P$, Struyf $S$, Schols D, Durinx C, Wuyts A, Lenaerts J-P, De Clercq E, De Meester I, Van Damme J. Processing by CD26/dipeptidyl-peptidase IV reduces the chemotactic and anti-HIV-1 activity of stromal-cell-derived factor-1a. FEBS Lett. 1998;432:73-6.

23. Delgado MB, Clark-Lewis I, Loetscher $\mathrm{P}$, Langen $\mathrm{H}$, Thelen $\mathrm{M}$, Baggiolini $\mathrm{M}$, Wolf M. Rapid inactivation of stromal cell-derived factor-1 by cathepsin $G$ associated with lymphocytes. Eur J Immunol. 2001:31:699-707.

24. McQuibban GA, Butler GS, Gong J-H, Bendall L, Power C, Clark-Lewis I, Overall CM. Matrix metalloproteinase activity inactivates the CXC chemokine stromal cell-derived factor-1. J Biol Chem. 2001;276:43503-8.

25. Valenzuela-Fernández A, Planchenault T, Baleux F, Staropoli I, Le-Barillec K, Leduc D, Delaunay T, Lazarini F, Virelizier J-L, Chignard M. Leukocyte elastase negatively regulates stromal cell-derived factor-1 (SDF-1)/CXCR4 binding and functions by amino-terminal processing of SDF-1 and CXCR4 J Biol Chem. 2002;277:15677-89.

26. Ye M, Kim S, Park K. Issues in long-term protein delivery using biodegradable microparticles. J Control Release. 2010;146:241-60.

27. Zamani M, Prabhakaran MP, San Thian E, Ramakrishna S. Controlled delivery of stromal derived factor-1a from poly lactic-co-glycolic acid core-shell particles to recruit mesenchymal stem cells for cardiac regeneration. J Colloid Interface Sci. 2015;451:144-52.

28. Ratanavaraporn J, Furuya $H$, Kohara $H$, Tabata $Y$. Synergistic effects of the dual release of stromal cell-derived factor-1 and bone morphogenetic protein-2 from hydrogels on bone regeneration. Biomaterials. 2011;32: 2797-811. 
29. He X, Ma J, Jabbari E. Migration of marrow stromal cells in response to sustained release of stromal-derived factor-1alpha from poly(lactide ethylene oxide fumarate) hydrogels. Int J Pharm. 2010;390:107-16.

30. Song M, Jang H, Lee J, Kim JH, Kim SH, Sun K, Park Y. Regeneration of chronic myocardial infarction by injectable hydrogels containing stem cell homing factor SDF-1 and angiogenic peptide Ac-SDKP. Biomaterials. 2014; 35:2436-45

31. Purcell BP, Elser JA, Mu AB, Margulies KB, Burdick JA. Synergistic effects of SDF-1 alpha chemokine and hyaluronic acid release from degradable hydrogels on directing bone marrow derived cell homing to the myocardium. Biomaterials. 2012;33:7849-57.

32. Zhang G, Nakamura Y, Wang X, Hu Q, Suggs $\sqcup$, Zhang J. Controlled release of stromal cell-derived factor-1alpha in situ increases c-kit + cell homing to the infarcted heart. Tissue Eng. 2007;13:2063-71.

33. Pereira CL, Goncalves RM, Peroglio M, Pattappa G, D’Este M, Eglin D, Barbosa MA, Alini M, Grad S. The effect of hyaluronan-based delivery of stromal cell-derived factor-1 on the recruitment of MSCs in degenerating intervertebral discs. Biomaterials. 2014;35:8144-53.

34. Thevenot PT, Nair AM, Shen J, Lotfi P, Ko CY, Tang L. The effect of incorporation of SDF-1alpha into PLGA scaffolds on stem cell recruitment and the inflammatory response. Biomaterials. 2010;31: 3997-4008.

35. Kimura Y, Tabata Y. Controlled release of stromal-cell-derived factor-1 from gelatin hydrogels enhances angiogenesis. J Biomater Sci Polym Ed. 2010;21: 37-51.

36. Koh HS, Yong T, Chan CK, Ramakrishna S. Enhancement of neurite outgrowth using nano-structured scaffolds coupled with laminin. Biomaterials. 2008;29:3574-82.

37. Tirella A, Magliaro C, Penta M, Troncone M, Pimentel R, Ahluwalia A. Sphyga: a multiparameter open source tool for fabricating smart and tunable hydrogel microbeads. Biofabrication. 2014;6:025009.

38. Hunt JN, Feldman KE, Lynd NA, Deek J, Campos LM, Spruell JM, Hernandez BM, Kramer EJ, Hawker CJ. Tunable, high modulus hydrogels driven by ionic coacervation. Adv Mater. 2011;23:2327-31.

39. Chen F-m, Zhao Y-m, Wu H, Deng Z-h, Wang Q-t, Zhou W, Liu Q, Dong G-y, Li K, Wu Z-f, Jin Y. Enhancement of periodontal tissue regeneration by locally controlled delivery of insulin-like growth factor-I from dextran-co-gelatin microspheres. J Control Release. 2006; 114:209-22

40. Liao IC, Wan AC, Yim EK, Leong KW. Controlled release from fibers of polyelectrolyte complexes. J Control Release. 2005;104:347-58.

41. Hamman JH. Chitosan based polyelectrolyte complexes as potential carrier materials in drug delivery systems. Mar Drugs. 2010;8:1305-22.

42. Carlsson F, Linse P, Malmsten M. Monte Carlo simulations of polyelectrolyteprotein complexation. J Phys Chem B. 2001;105:9040-9.

43. Ball V, Winterhalter $M$, Schwinte $P$, Lavalle $P$, Voegel JC, Schaaf $P$. Complexation mechanism of bovine serum albumin and poly(allylamine hydrochloride). J Phys Chem B. 2002;106:2357-64.

44. Chu HH, Chen CW, Huard J, Wang YD. The effect of a heparin-based coacervate of fibroblast growth factor-2 on scarring in the infarcted myocardium. Biomaterials. 2013;34:1747-56.

45. Roy K, Mao HQ, Huang SK, Leong KW. Oral gene delivery with chitosan-DNA nanoparticles generates immunologic protection in a murine model of peanut allergy. Nat Med. 1999;5:387-91.

46. Kizilay E, Kayitmazer AB, Dubin PL. Complexation and coacervation of polyelectrolytes with oppositely charged colloids. Adv Colloid Interface Sci. 2011;167:24-37.

47. Yu J, Wang A, Tang Z, Henry J, Li-Ping Lee B, Zhu Y, Yuan F, Huang F, Li S. The effect of stromal cell-derived factor-1alpha/heparin coating of biodegradable vascular grafts on the recruitment of both endothelial and smooth muscle progenitor cells for accelerated regeneration. Biomaterials. 2012;33:8062-74.

48. Niu LN, Jiao K, Qi YP, Nikonov S, Yiu CKY, Arola DD, Gong SQ, El-Marakby A, Carrilho MRO, Hamrick MW, Hargreaves KM, Diogenes A, Chen JH, Pashley $\mathrm{DH}$, Tay FR. Intrafibrillar silicification of collagen scaffolds for sustained release of stem cell homing chemokine in hard tissue regeneration. FASEB J. 2012;26:4517-29.

49. Zhu Y, Hoshi R, Chen S, Yi J, Duan C, Galiano RD, Zhang HF, Ameer GA. Sustained release of stromal cell derived factor-1 from an antioxidant thermoresponsive hydrogel enhances dermal wound healing in diabetes. J Control Release. 2016;238:114-22.
50. Dealwis C, Fernandez EJ, Thompson DA, Simon RJ, Siani MA, Lolis E. Crystal structure of chemically synthesized [N33A] stromal cell-derived factor 1a, a potent ligand for the HIV-1 "fusin" coreceptor. Proc Natl Acad Sci. 1998;95: 6941-6.

51. Lee KW, Johnson NR, Gao J, Wang Y. Human progenitor cell recruitment via SDF-1alpha coacervate-laden PGS vascular grafts. Biomaterials. 2013;34: 9877-85.

52. Mantripragada VP, Jayasuriya AC. IGF-1 release kinetics from chitosan microparticles fabricated using environmentally benign conditions. Mater Sci Eng C Mater Biol Appl. 2014;42:506-16.

53. des Rieux A, Ucakar B, Mupendwa BP, Colau D, Feron O, Carmeliet P, Preat V. 3D systems delivering VEGF to promote angiogenesis for tissue engineering. J Control Release. 2011;150:272-8.

54. Sadir R, Baleux F, Grosdidier A, Imberty A, Lortat-Jacob H. Characterization of the stromal cell-derived factor-1alpha-heparin complex. J Biol Chem. 2001; 276:8288-96.

55. Bladergroen BA, Siebum B, Siebers-Vermeulen KGC, Van Kuppevelt TH, Poot AA, Feijen J, Figdor CG, Torensma R. In vivo recruitment of hematopoietic cells using stromal cell-derived factor 1 alpha-loaded heparinized three-dimensional collagen scaffolds. Tissue Eng A. 2009;15: 1591-9.

56. Amara A, Lorthioir O, Valenzuela A, Magerus A, Thelen M, Montes M, Virelizier J-L, Delepierre M, Baleux F, Lortat-Jacob H. Stromal cell-derived factor-1a associates with heparan sulfates through the first $\beta$-strand of the chemokine. J Biol Chem. 1999;274:23916-25.

57. Baumann L, Prokoph S, Gabriel C, Freudenberg U, Werner C, Beck-Sickinger AG. A novel, biased-like SDF-1 derivative acts synergistically with starPEGbased heparin hydrogels and improves eEPC migration in vitro. J Control Release. 2012;162:68-75.

58. Krieger JR, Ogle ME, McFaline-Figueroa J, Segar CE, Temenoff JS, Botchwey EA. Spatially localized recruitment of anti-inflammatory monocytes by SDF1 alpha-releasing hydrogels enhances microvascular network remodeling. Biomaterials. 2016;77:280-90.

59. Fernandez-Muinos T, Recha-Sancho L, Lopez-Chicon P, Castells-Sala C, Mata A, Semino CE. Bimolecular based heparin and self-assembling hydrogel for tissue engineering applications. Acta Biomater. 2015;16:35-48.

60. Cuchiara ML, Horter KL, Banda OA, West JL. Covalent immobilization of stem cell factor and stromal derived factor 1 a for in vitro culture of hematopoietic progenitor cells. Acta Biomater. 2013;9: 9258-69.

61. Kang SN, Park C, Kim SM, Park KW, Park BJ, Han DK, Joung YK. Effect of stromal cell derived factor-1a release from heparin-coated Co-Cr stent substrate on the recruitment of endothelial progenitor cells. Macromol Res. 2015;23:1159-67.

62. Patel S, Kurpinski K, Quigley R, Gao HF, Hsiao BS, Poo MM, Li S. Bioactive nanofibers: synergistic effects of nanotopography and chemical signaling on cell guidance. Nano Lett. 2007;7:2122-8.

63. Tsurkan MV, Levental KR, Freudenberg U, Werner C. Enzymatically degradable heparin-polyethylene glycol gels with controlled mechanical properties. Chem Commun (Camb). 2010;46:1141-3.

64. Schantz J-T, Chim H, Whiteman M. Cell guidance in tissue engineering: SDF-1 mediates site-directed homing of mesenchymal stem cells within three-dimensional polycaprolactone scaffolds. Tissue Eng. 2007;13:2615-24.

65. Cross DP, Wang C. Stromal-derived factor-1 alpha-loaded PLGA microspheres for stem cell recruitment. Pharm Res. 2011;28:2477-89.

66. Wu SZ, Li L, Wang G, Shen WW, Xu YL, Liu Z, Zhuo ZX, Xia HM, Gao YH, Tan KB. Ultrasound-targeted stromal cell-derived factor-1-loaded microbubble destruction promotes mesenchymal stem cell homing to kidneys in diabetic nephropathy rats. Int J Nanomedicine. 2014;9:5639-51.

67. Wang G, Siggers $K$, Zhang S, Jiang H, Xu Z, Zernicke RF, Matyas J, Uludag H. Preparation of BMP-2 containing bovine serum albumin (BSA) nanoparticles stabilized by polymer coating. Pharm Res. 2008;25:2896-909.

68. Ding D, Zhu ZS, Li RT, Li XL, Wu W, Jiang XQ, Liu BR. Nanospheresincorporated implantable hydrogel as a trans-tissue drug delivery system. ACS Nano. 2011:5:2520-34.

69. Matsusaki M, Akashi M. Functional multilayered capsules for targeting and local drug delivery. Expert Opin Drug Deliv. 2009;6:1207-17.

70. Mu B, Liu P, Tang ZB, Du PC, Dong Y. Temperature and pH dualresponsive cross-linked polymeric nanocapsules with controllable structures via surface-initiated atom transfer radical polymerization from templates. Nanomed Nanotechnol Biol Med. 2011;7:789-96. 
71. Fleige E, Quadir MA, Haag R. Stimuli-responsive polymeric nanocarriers for the controlled transport of active compounds: concepts and applications. Adv Drug Deliv Rev. 2012;64:866-84.

72. Yang J, van Lith R, Baler K, Hoshi RA, Ameer GA. A thermoresponsive biodegradable polymer with intrinsic antioxidant properties. Biomacromolecules. 2014;15:3942-52.

73. Kim DH, Seo YK, Thambi T, Moon GJ, Son JP, Li G, Park JH, Lee JH, Kim HH, Lee DS, Bang OY. Enhancing neurogenesis and angiogenesis with target delivery of stromal cell derived factor-1 alpha using a dual ionic $\mathrm{pH}$ sensitive copolymer. Biomaterials. 2015;61:115-25.

74. Na K, Kim S, Park K, Kim K, Woo DG, Kwon IC, Chung HM, Park KH. Heparin/ poly(L-lysine) nanoparticle-coated polymeric microspheres for stem-cell therapy. J Am Chem Soc. 2007;129:5788-9.

75. Chen FM, Wu LA, Zhang M, Zhang R, Sun HH. Homing of endogenous stem/progenitor cells for in situ tissue regeneration: promises, strategies, and translational perspectives. Biomaterials. 2011;32:3189-209.

76. Richardson TP, Peters MC, Ennett AB, Mooney DJ. Polymeric system for dual growth factor delivery. Nat Biotechnol. 2001;19:1029-34.

77. Cleary MA, Geiger E, Grady C, Best C, Naito Y, Breuer C. Vascular tissue engineering: the next generation. Trends Mol Med. 2012;18: 394-404.

78. Chen FM, Chen R, Wang XJ, Sun HH, Wu ZF. In vitro cellular responses to scaffolds containing two microencapulated growth factors. Biomaterials. 2009;30:5215-24

79. Kim HKW, Moran ME, Salter RB. The potential for regeneration of articularcartilage in defects created by chondral shaving and subchondral abrasion an experimental investigation in rabbits. J Bone Joint Surg Am. 1991;73A: $1301-15$.

80. Altman RD, Kates J, Chun LE, Dean DD, Eyre D. Preliminary-observations of chondral abrasion in a canine model. Ann Rheum Dis. 1992;51:1056-62.

81. Shapiro F, Koide S, Glimcher MJ. Cell origin and differentiation in the repair of full-thickness defects of articular-cartilage. J Bone Joint Surg Am. 1993; 75A:532-53.

82. Hunziker EB. Articular cartilage repair: basic science and clinical progress. A review of the current status and prospects. Osteoarthr Cartil. 2002;10:432-63.

83. Hunziker EB. Articular cartilage repair: are the intrinsic biological constraints undermining this process insuperable? Osteoarthr Cartil. 1999;7:15-28.

84. Wei L, Kanbe K, Lee M, Wei XC, Pei M, Sun XJ, Terek R, Chen Q. Stimulation of chondrocyte hypertrophy by chemokine stromal cell-derived factor 1 in the chondro-osseous junction during endochondral bone formation. Dev Biol. 2010;341:236-45.

85. Zhang W, Chen J, Tao J, Jiang Y, Hu C, Huang L, Ji J, Ouyang HW. The use of type 1 collagen scaffold containing stromal cell-derived factor- 1 to create a matrix environment conducive to partial-thickness cartilage defects repair. Biomaterials. 2013;34:713-23.

86. Sukegawa A, Iwasaki N, Kasahara Y, Onodera T, Igarashi T, Minami A. Repair of rabbit osteochondral defects by an acellular technique with an ultrapurified alginate gel containing stromal cell-derived factor-1. Tissue Eng Part A. 2012;18:934-45.

87. Bai Y, Yin G, Huang Z, Liao X, Chen X, Yao Y, Pu X. Localized delivery of growth factors for angiogenesis and bone formation in tissue engineering. Int Immunopharmacol. 2013;16:214-23.

88. Pelissier P, Villars F, Mathoulin-Pelissier S, Bareille R, Lafage-Proust MH, Vilamitjana-Amedee J. Influences of vascularization and osteogenic cells on heterotopic bone formation within a madreporic ceramic in rats. Plast Reconstr Surg. 2003;111:1932-41.

89. Smith MK, Peters MC, Richardson TP, Garbern JC, Mooney DJ. Locally enhanced angiogenesis promotes transplanted cell survival. Tissue Eng. 2004;10:63-71.

90. Rouwkema J, Rivron NC, van Blitterswijk CA. Vascularization in tissue engineering. Trends Biotechnol. 2008;26:434-41.

91. Chen P, Tao J, Zhu S, Cai Y, Mao Q, Yu D, Dai J, Ouyang H. Radially oriented collagen scaffold with SDF-1 promotes osteochondral repair by facilitating cell homing. Biomaterials. 2015;39:114-23.

92. Brouwer KM, Daamen WF, van Lochem N, Reijnen D, Wijnen $R M H$, van Kuppevelt TH. Construction and in vivo evaluation of a dual layered collagenous scaffold with a radial pore structure for repair of the diaphragm. Acta Biomater. 2013;9:6844-51.

93. Brouwer KM, van Rensch P, Harbers VEM, Geutjes PJ, Koens MJW, Wijnen $\mathrm{RMH}$, Daamen WF, van Kuppevelt TH. Evaluation of methods for the construction of collagenous scaffolds with a radial pore structure for tissue engineering. J Tissue Eng Regen Med. 2011;5:501-4.

94. Hwang HD, Lee JT, Koh JT, Jung HM, Lee HJ, Kwon TG. Sequential treatment with SDF-1 and BMP-2 potentiates bone formation in calvarial defects. Tissue Eng A. 2015;21:2125-35.

95. Lee $\mathrm{CH}$, Jin MU, Jung HM, Lee JT and Kwon TG. Effect of Dual Treatment with SDF-1 and BMP-2 on Ectopic and Orthotopic Bone Formation. PLoS One. 2015;10(3):e0120051.

96. Holloway JL, Ma H, Rai R, Hankenson KD, Burdick JA. Synergistic effects of SDF-1 and BMP-2 delivery from proteolytically degradable hyaluronic acid hydrogels for bone repair. Macromol Biosci. 2015;15: $1218-23$.

97. Jin QM and Giannobile WV. SDF-1 Enhances Wound Healing of Critical-Sized Calvarial Defects beyond Self-Repair Capacity. PLoS One. 2014;9(5):e97035.

98. Rybalko VY, Pham CB, Hsieh PL, Hammers DW, Merscham-Banda M, Suggs LJ, Farrar RP. Controlled delivery of SDF-1 alpha and IGF-1: CXCR4(+) cell recruitment and functional skeletal muscle recovery. Biomater Sci. 2015;3: 1475-86.

99. Kleinheinz J, Stratmann U, Joos U, Wiesmann HP. VEGF-activated angiogenesis during bone regeneration. J Oral Maxillofac Surg. 2005;63: 1310-6.

100. Bussolino F, Albini A, Camussi G, Presta M, Viglietto G, Ziche M, Persico G. Role of soluble mediators in angiogenesis. Eur J Cancer. 1996;32A:2401-12.

101. Folkman J. Opinion - angiogenesis: an organizing principle for drug discovery? Nat Rev Drug Discov. 2007;6:273-86.

102. Zhu W, Boachie-Adjei O, Rawlins BA, Frenkel B, Boskey AL, Ivashkiv LB, Blobel CP. A novel regulatory role for stromal-derived factor-1 signaling in bone morphogenic protein-2 osteogenic differentiation of mesenchymal C2C12 cells. J Biol Chem. 2007;282:18676-85.

103. Hosogane N, Huang ZP, Rawlins BA, Liu X, Boachie-Adjei O, Boskey AL, Zhu W. Stromal derived factor-1 regulates bone morphogenetic protein 2induced osteogenic differentiation of primary mesenchymal stem cells. Int J Biochem Cell Biol. 2010;42:1132-41.

104. Cei S, Kandler B, Fugl A, Gabriele M, Hollinger JO, Watzek G, Grubert R. Bone marrow stromal cells of young and adult rats respond similarly to platelet-released supernatant and bone morphogenetic protein-6 in vitro. J Periodontol. 2006;77:699-706.

105. Fujii M, Takeda K, Imamura T, Aoki H, Sampath TK, Enomoto S, Kawabata M, Kato M, Ichijo H, Miyazono K. Roles of bone morphogenetic protein type I receptors and smad proteins in osteoblast and chondroblast differentiation. Mol Biol Cell. 1999;10:3801-13.

106. Gu K, Zhang LX, Jin TC, Rutherford RB. Identification of potential modifiers of Runx2/Cbfa1 activity in C2C12 cells in response to bone morphogenetic protein-7. Cells Tissues Organs. 2004;176:28-40.

107. Zhu W, Kim J, Cheng C, Rawlins BA, Boachie-Adjei O, Crystal RG, Hidaka C. Noggin regulation of bone morphogenetic protein (BMP) 2/7 heterodimer activity in vitro. Bone. 2006:39:61-71.

108. Wang CK, Ho ML, Wang GJ, Chang JK, Chen CH, Fu YC, Fu HH. Controlledrelease of rhBMP-2 carriers in the regeneration of osteonecrotic bone. Biomaterials. 2009;30:4178-86.

109. Benglis D, Wang MY, Levi AD. A comprehensive review of the safety profile of bone morphogenetic protein in spine surgery. Neurosurgery. 2008;62 423-31.

110. Chen NF, Smith ZA, Stiner E, Armin S, Sheikh H, Khoo LT. Symptomatic ectopic bone formation after off-label use of recombinant human bone morphogenetic protein-2 in transforaminal lumbar interbody fusion Report of 4 cases. J Neurosurg Spine. 2010;12:40-6.

111. Zhou YS, Ni YW, Liu YS, Zeng BJ, Xu YW, Ge WS. The role of simvastatin in the osteogenesis of injectable tissue-engineered bone based on human adipose-derived stromal cells and platelet-rich plasma. Biomaterials. 2010;31: 5325-35.

112. Stein D, Lee YJ, Schmid MJ, Killpack B, Genrich MA, Narayana N, Marx DB, Cullen DM, Reinhardt RA. Local simvastatin effects on mandibular bone growth and inflammation. J Periodontol. 2005;76:1861-70.

113. Nyan M, Sato D, Oda M, Machida T, Kobayashi H, Nakamura T, Kasugai S. Bone formation with the combination of simvastatin and calcium sulfate in critical-sized rat calvarial defect. J Pharmacol Sci. 2007;104:384-6.

114. Wu Z, Liu C, Zang G, Sun H. The effect of simvastatin on remodelling of the alveolar bone following tooth extraction. Int J Oral Maxillofac Surg. 2008:37: $170-6$. 
115. Ozec I, Kilic E, Gumus C, Goze F. Effect of local simvastatin application on mandibular defects. J Craniofac Surg. 2007;18:546-50

116. Han XG, Yang N, Cui YY, Xu YS, Dang GT, Song CL. Simvastatin mobilizes bone marrow stromal cells migrating to injured areas and promotes functional recovery after spinal cord injury in the rat. Neurosci Lett. 2012; 521:136-41.

117. Liu YS, Ou ME, Liu H, Gu M, Lv LW, Fan C, Chen T, Zhao XH, Jin CY, Zhang $X$, Ding $Y$, Zhou YS. The effect of simvastatin on chemotactic capability of SDF-1alpha and the promotion of bone regeneration. Biomaterials. 2014;35: 4489-98.

118. Roger VL, Go AS, Lloyd-Jones DM, Adams RJ, Berry JD, Brown TM Carnethon MR, Dai S, De Simone G, Ford ES. Heart disease and stroke statistics - 2011 update a report from the American Heart Association. Circulation. 2011;123:e18-209.

119. Ma J, Ge JB, Zhang SH, Sun AJ, Shen JY, Chen LL, Wang KQ, Zou YZ. Time course of myocardial stromal cell-derived factor 1 expression and beneficial effects of intravenously administered bone marrow stem cells in rats with experimental myocardial infarction. Basic Res Cardiol. 2005;100:217-23.

120. Tang YL, Qian KP, Zhang YC, Shen LP, Phillips MI. Mobilizing of haematopoietic stem cells to ischemic myocardium by plasmid mediated stromal-cell-derived factor-1 alpha (SDF-1 alpha) treatment. Regul Pept. 2005;125:1-8.

121. MacArthur JW, Purcell BP, Shudo Y, Cohen JE, Fairman A, Trubelja A, Patel J, Hsiao P, Yang E, Lloyd K. Sustained release of engineered stromal cellderived factor 1-a from injectable hydrogels effectively recruits endothelial progenitor cells and preserves ventricular function after myocardial infarction. Circulation. 2013;128:S79-86.

122. Rabbany SY, Pastore J, Yamamoto M, Miller T, Rafii S, Aras R, Penn M. Continuous delivery of stromal cell-derived factor- 1 from alginate scaffolds accelerates wound healing. Cell Transplant. 2010;19:399-408.

123. Addington C, Heffernan J, Millar-Haskell C, Tucker E, Sirianni R, Stabenfeldt S. Enhancing neural stem cell response to SDF-1a gradients through hyaluronic acid-laminin hydrogels. Biomaterials. 2015;72:11-9.

\section{Submit your next manuscript to BioMed Central} and we will help you at every step:

- We accept pre-submission inquiries

- Our selector tool helps you to find the most relevant journal

- We provide round the clock customer support

- Convenient online submission

- Thorough peer review

- Inclusion in PubMed and all major indexing services

- Maximum visibility for your research

Submit your manuscript at www biomedcentral.com/submit

\section{(O) BioMed Central}

